\author{
Slawomir Dorocki, Wioletta Kilar, Tomasz Rachwal \\ Uniwersytet Pedagogiczny \\ im. Komisji Edukacji Narodowej \\ w Krakowie
}

\title{
Założenia i cele Projektu „Krok w przedsiębiorczość” dla nauczycieli szkół ponadgimnazjalnych
}

Przedsiębiorczość, definiowana zarówno w szerokim ujęciu, jako postawa człowieka kreatywnego, zdolnego do aktywnego uczestnictwa w życiu społeczno-gospodarczym, jak i nieco w węższym zakresie, jako zdolność oraz chęć do założenia i prowadzenia własnego przedsiębiorstwa (Brzozowski 2007; Rachwał 2005a, b, 2006), jest jednym z podstawowych czynników rozwoju społeczno-gospodarczego układów przestrzennych różnej skali (Kurek, Rachwał 2010a; Naudé 2008; Zioło 2006, 2007, 2009; Zioło, Rachwał, 2005, 2006, 2007, 2008, 2009). Rozwój ducha przedsiębiorczości w społeczeństwie oraz przedsiębiorczości rozumianej jako wyraz aktywności przedsiębiorców jest uważany za szczególnie ważny czynnik wzrostu gospodarczego w krajach transformujących swoje gospodarki, szczególnie w Polsce oraz innych krajach Europy Środkowo-Wschodniej. Należy przy tym zauważyć, za W. Naudé (2008), że w krajach rozwijających się przedsiębiorczość odgrywa swoją rolę głównie w przyspieszeniu wzrostu gospodarczego i generowaniu impulsów do transformacji strukturalnej gospodarek, natomiast w krajach wysokorozwiniętych gospodarczo jest ona rozpatrywana w dużej mierze w kontekście pozyskania nowych źródeł wzrostu wydajności pracy, która leży u podstaw konkurencyjności.

Jednocześnie współczesne tendencje rozwoju cywilizacyjnego, związane z budową gospodarki opartej na wiedzy (Zioło 2008) i kształtowaniem społeczeństwa informacyjnego (Borowiec, Dorocki, Jenner 2009; Gierańczyk 2009; Zioło 2009) wymagają stałego unowocześnienia procesu dydaktycznego na wszystkich poziomach edukacji, tak aby dostosować cele, treści, metody i zakładane efekty kształcenia szkolnego do wyzwań czekających młode pokolenie we współczesnym świecie, w tym do znalezienia i wykonywania pracy najemnej i/lub samozatrudnienia, poprzez zaprojektowanie, założenie i poprowadzenie własnej firmy (Kurek, Rachwał 2010b; Rachwał 2004, 2010; Wach 2007). Ważną funkcję w tym zakresie pełni edukacja ekonomiczna, której znaczenie uwidacznia się szczególnie w czasie trwającego w Europie od początku 2008 r. kryzysu gospodarczego. W warunkach spadku produkcji i ograniczania zatrudnienia okazało się, że dla wielu osób praca na własnych rachunek staje się jedynym możliwym sposobem zapewnienia sobie godziwych środków do życia. Należy zdawać sobie sprawę z faktu, że umiejętność stworzenia i poprowadzenia własnego przedsiębiorstwa, szczególnie w trudnych warunkach recesji gospodarczej, nie wynika tylko z wrodzonych zdolności, ale jest także wynikiem kształtowania przedsiębiorczej postawy oraz nabywania niezbędnych do tego umiejętności w toku edukacji szkolnej (Rachwał 2006; 2010). 
Przedsiębiorczość odgrywa więc ogromną rolę nie tylko w polskim, ale także europejskim systemie edukacji. Jest jedną z kompetencji kluczowych w europejskim obszarze edukacyjnym (ryc. 1), obok m.in. posługiwania się językiem ojczystym i obcym, a także kompetencji matematycznych i informatycznych (Recommendation 2006, Kompetencje 2005, 2007).

Ryc. 1. Kompetencje kluczowe w europejskim obszarze edukacyjnym

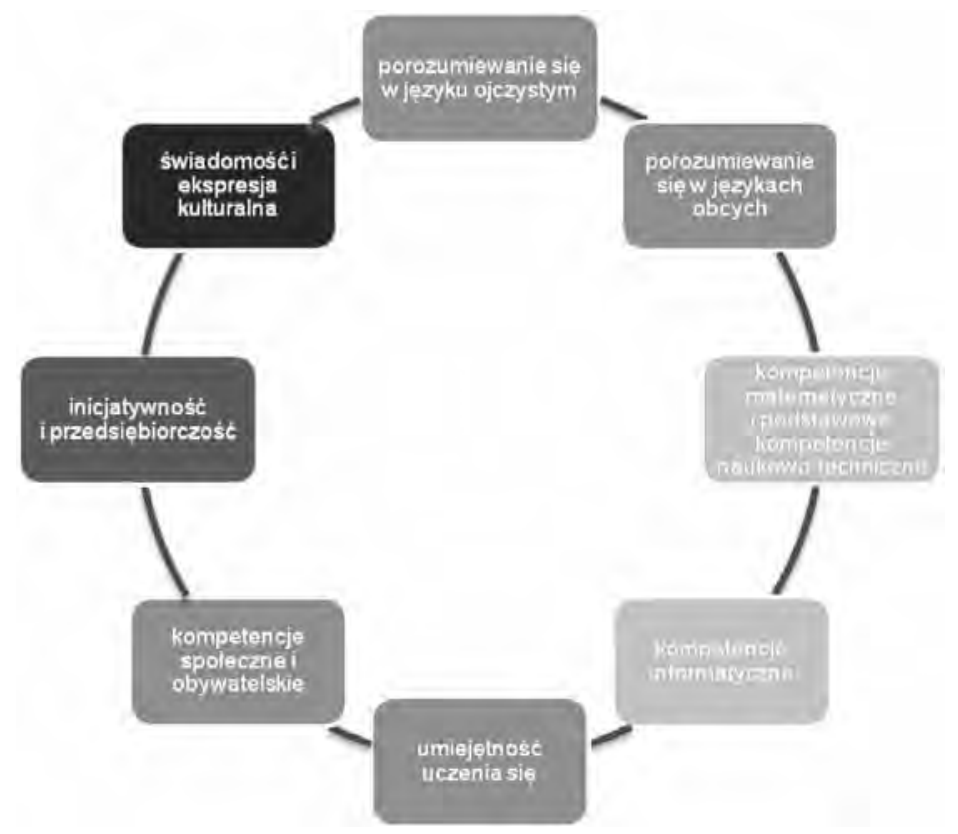

Kompetencje kształtowane w proponowanej strategii kształcenia:

kompetencja główna,

kompetencje podstawowe bezpośrednio powiązane z kompetencją główną,

kompetencje dodatkowe, których kształtowanie jest wspierane w proponowanej strategii,

kompetencja pozostała, w niewielkim stopniu wspierana przez realizację strategii.

Źródło: Innowacyjna strategia kształcenia w zakresie przedsiębiorczości oraz kształtowania kompetencji informatycznych i matematycznych z wykorzystaniem wirtualnej Otwartej Platformy Edukacyjnej opracowana w ramach Projektu „Krok w przedsiębiorczość” (wstępna wersja), Nowa Era, Warszawa 2011.

Bardzo często kształcenie w zakresie przedsiębiorczości jest rozumiane jako przygotowanie do założenia i prowadzenia własnej firmy. Jednak należy zwrócić uwagę, za A. Szabó (2008), iż europejscy politycy zgadzają się obecnie z opinią, że zakres kształcenia w obrębie przedsiębiorczości jest znacznie szerszy niż tylko szkolenie na temat rozpoczęcia działalności gospodarczej czy pisania biznesplanu, gdyż obejmuje on także rozwój wielu cech osobowych, takich jak kreatywność, inicjatywa, pewność siebie i in. W świetle definicji przyjętej przez Komisję Europejską, kompetencje określone jako inicjatywność i przedsiębiorczość oznaczają zdolność osoby do wcielania pomysłów w czyn. Mieszczą się w nich takie cechy, jak kreatywność, innowacyjność i podejmowanie ryzyka, jak również zdolność do planowania przedsięwzięć i prowadzenia ich dla osiągnięcia zamierzonych celów. Kompetencje te stanowią wsparcie dla 
indywidualnych osób nie tylko w ich codziennym życiu prywatnym i społecznym, ale także w miejscu ich pracy, pomagając uzyskać świadomość kontekstu pracy oraz zdolność wykorzystywania szans. Są one podstawą konkretniejszych umiejętności i wiedzy potrzebnych tym, którzy podejmują przedsięwzięcia o charakterze społecznym lub handlowym, lub w nich uczestniczą. Powinny one obejmować świadomość wartości etycznych i promować dobre zarządzanie (Commission 2006, Kompetencje 2007). Na potrzeby edukacji szkolnej przyjęto więc w Projekcie dosyć szerokie rozumienie przedsiębiorczości - podobne stanowisko zajmuje Rachwał (2005b, 2006). Nie można jednak tym samym negować faktu, że jednym z ważnych przejawów, jeśli nie najważniejszym, przedsiębiorczości jest założenie i prowadzenie własnego przedsiębiorstwa. Ten punkt widzenia na przedsiębiorczość stanowi bazę programową do realizacji Projektu „Krok w przedsiębiorczość”, w ramach którego wypracowana zostanie Innowacyjna strategia kształcenia (2011), pozwalająca, obok przedsiębiorczości, kształtować większość z ośmiu europejskich kompetencji kluczowych (ryc. 1).

Potrzeba kształcenia w zakresie przedsiębiorczości nie wynika tylko z samego faktu zaliczenia jej do listy kompetencji kluczowych. W ostatnich latach powszechnie zauważany jest, zarówno przez pracodawców, jak i specjalistów od rynku pracy, brak dostatecznych kompetencji absolwentów szkół do podjęcia pracy i samozatrudnienia, wynikający z niedostatecznego wyposażenia $\mathrm{w}$ wiedzę i umiejętności związane $\mathrm{z}$ funkcjonowaniem $\mathrm{w}$ świecie biznesu oraz umiejętności komputerowe i matematyczne. Jest to efektem m.in. ograniczenia w XX w. edukacji ekonomicznej w Polsce (a także w wielu innych krajach europejskich, por. Szabó 2008) do szkolnictwa wyższego, ewentualnie szkół średnich, głównie jednak o profilu ekonomicznym (Rachwał, Kurek 2010). W efekcie, postawy przedsiębiorcze w kształceniu ogólnym kształtowane są tylko w ramach - bardzo często marginalnie traktowanego w szkołach ponadgimnazjalnych - przedmiotu podstawy przedsiębiorczości oraz częściowo w ramach przedmiotu wiedza o społeczeństwie w gimnazjum. Tę niekorzystną sytuację pogłębia fakt, że przedsiębiorczość nie jest przedmiotem maturalnym, choć stanowi podstawowy filar europejskiej strategii edukacyjnej, a modernizacja podstawy programowej i wprowadzenie w czasie trwającej w Polsce reformy systemu edukacji dodatkowego, fakultatywnego przedmiotu ekonomia w praktyce, niekoniecznie podniesienie rangę edukacji ekonomicznej w polskiej szkole (Rachwał 2009).

Obserwuje się też tradycyjne podejście do nauczania przedsiębiorczości (m.in. Tracz, Rachwał 2007, 2008; E. i W. Osuch 2005) - nauczyciele w małym stopniu wykorzystują na lekcjach gry symulacyjne, np. dotyczące tworzenia wirtualnej firmy, uważając je za zbyt trudne do przeprowadzenia oraz ze względów organizacyjnych. Analiza wyników badań nauczycieli przeprowadzonych na potrzeby Projektu wykazała, że wśród najczęściej stosowanych metod dydaktycznych są: ćwiczenia, pogadanka i wykład (razem 44\% stosowanych metod). Tylko 1/3 ankietowanych stosuje w nauczaniu metody aktywizujące. Wśród wymienionych przyczyn stosowania metod podających wskazywane są głównie: brak możliwości technicznych, brak środków dydaktycznych dostosowanych do potrzeb lekcji, zbyt liczne klasy i ograniczenia czasowe. Wśród innych metod stosowanych przez nauczycieli znalazła się praca projektowa w grupie. Nauczyciele zwracali uwagę na potrzebę stosowania metod, które wymuszają na uczniach samodzielność i rozwijają umiejętność współpracy, jednak ich stosowanie w praktyce napotyka na szereg barier.

Wykorzystanie w szkołach bardziej zaawansowanych środków dydaktycznych jest więc znikome. W większości przypadków powodem tego stanu rzeczy jest brak pomocy dydaktycznych, czasu lub dostępu do sal (np. komputerowych), w których znajdują się te narzędzia. 
Spośród najczęściej wykorzystywanych środków dydaktycznych nauczyciele wymienili podręczniki szkolne, książki i teksty źródłowe. Następne w kolejności były komputery i pomoce dydaktyczne do pokazu oraz pomoce audiowizualne. Najrzadziej wskazywane były zeszyty ćwiczeń oraz inne, m.in. tablice interaktywne. Stan ten - w kontekście potrzeby kształtowania umiejętności i postaw - jest wysoce niezadowalający.

Badania przeprowadzone w ramach Projektu potwierdziły spostrzeżenia niektórych autorów nt. stanu edukacji w zakresie przedsiębiorczości. Zdaniem m.in. P. Szeligi „Do systemu kształcenia wprowadzono edukację przedsiębiorczą, ale dziś zajmujemy się często edukacją ekonomiczną. Zamiast uczyć postaw przedsiębiorczych, zaradności, samodzielności, przekazujemy wiedzę o gospodarce, systemie gospodarczym. Sądzę, że dominacja makroekonomii, ujęć strukturalnych i systemowych oraz wiedzocentryczność programów nauczania przedsiębiorczości nie odpowiadają potrzebom chwili. To tak, jakby edukację zdrowotną zaczynać od zasad funkcjonowania systemu opieki zdrowotnej! Tego typu podejście jest pochodną akademickiego sposobu patrzenia na rzeczywistość, którą twórcy podręczników szkolnych traktują jako obiekt badań, a nie przedmiot przekształceń. Nic dziwnego, że młody człowiek nie widzi w tym miejsca dla siebie. Odrzuca niestrawne i dalekie od jego osobistych doświadczeń wielosłowie" (2007, s. 140-141). Również wcześniejsze badania M. Tracz i T. Rachwała (2007), których celem było: ustalenie rodzaju i częstotliwości stosowania metod aktywizujących w nauczaniu - uczeniu się podstaw przedsiębiorczości, poznanie opinii nauczycieli o stopniu wyposażenia szkół w środki dydaktyczne niezbędne do realizacji zadań związanych z nauczanym przedmiotem, ustalenie rodzajów środków dydaktycznych najczęściej wykorzystywanych na lekcjach podstaw przedsiębiorczości, wykazały, że nauczyciele są przekonani o konieczności stosowania metod aktywizujących, ale nie robią tego zbyt często. Ze względu na ograniczenia czasowe na realizację przedmiotu w ramowym planie nauczania oraz niedostateczne wyposażenie szkół w nowoczesne środki dydaktyczne często są zmuszeni do rezygnacji ze stosowania metod aktywizujących i najczęściej na lekcjach wykorzystują podręcznik. Wśród badanych nauczycieli 30\% wykorzystuje strony internetowe wybranych instytucji, a tylko $8,2 \%$ korzysta z programów komputerowych tematycznie związanych z lekcją. Generalnie zauważono, że uczniowie osiągają słabe wyniki kształcenia, a spośród wymienionych przyczyn takiego stanu rzeczy połowa nauczycieli $(46,7 \%)$ wskazała brak wystarczającej ilości czasu na lekcjach. Poza tym zwracano uwagę na brak motywacji uczniów (związany poniekąd z niemożnością wyboru podstaw przedsiębiorczości do zdawania na maturze) oraz brak innowacyjnych pomocy dydaktycznych. Brak czasu jest tym bardziej zauważalny, że ponad 75\% nauczycieli wykorzystuje czas na zajęciach w sposób efektywny lub bardzo efektywny. Wydaje się zatem zasadne bądź to zwiększenie liczby godzin dydaktycznych, bądź wykorzystanie metod pracy na odległość, które pozwalają na częściową realizację materiału poza szkołą.

Jednocześnie warto zwrócić uwagę, że różnorodność systemów kształcenia w poszczególnych krajach europejskich prowadzi do sytuacji, w których kompetencje w tym zakresie uzyskiwane w toku edukacji szkolnej kształtują się na różnym poziomie, co przekłada się na gorsze warunki dostępu części młodzieży do europejskiego rynku pracy. Chodzi tu głównie o młodzież z krajów transformujących swoje gospodarki, gdzie w okresie centralnego sterowania gospodarką ograniczano możliwość rozwoju własnej działalności gospodarczej i tym samym sukcesji firm oraz przekazywania doświadczeń przez rodziców. Wyraźnie jest to widoczne $\mathrm{w}$ analizach porównawczych, $\mathrm{m}$.in. prowadzonych $\mathrm{w}$ ramach europejskiego projektu badawczego „Fit for Business: Developing Business Competencies in School” (FIFOBI) „Zdolni do biznesu: kształtowanie kompetencji biznesowych uczniów” (Kurek, Rachwał 2010a). 
Należy sobie również zdawać sprawę z faktu, że w nowych warunkach rozwoju gospodarczego, związanych z kształtowaniem się cywilizacji informacyjnej, szybki postęp technologiczny skazuje na marginalizację osoby, które mają braki w posługiwaniu się technologią komputerową. Prowadzi to w warunkach dynamicznego rozwoju społeczeństwa informacyjnego do tzw. wykluczenia cyfrowego. Równie ważne, obok rozwijania kompetencji informatycznych, z punktu widzenia aktywnego uczestnictwa w gospodarce opartej na wiedzy, jest kształtowanie kompetencji matematycznych. Zwrócili na to słusznie uwagę autorzy raportu Centralnej Komisji Egzaminacyjnej nt. osiągnięć maturzystów w 2009 r., podkreślając, że ,trzeba uświadomić uczniom, że znajomość matematyki na poziomie podstawowym to fundament logicznego myślenia w każdym aspekcie życia", niezbędny w podejmowaniu życiowych decyzji ekonomicznych i prowadzeniu własnego biznesu. Niestety, wśród polskich uczniów obserwowane są słabe efekty kształcenia w zakresie umiejętności matematycznych (wg raportów CKE Osiagnięcia maturzystów w 2009 r. i 2010 r.; potwierdzają to także Badania OECD PISA 2009) oraz strach przed egzaminem maturalnym z tego przedmiotu (czego dowodem był niski odsetek osób wybierających go na maturze; w 2009 r. było to tylko 19\%). Matematyka, choć jest jednym z najważniejszych przedmiotów szkolnych, przegrała z biologią, wiedzą o społeczeństwie i geografią. Przywrócenie obligatoryjności matury z matematyki samo w sobie w niewielkim stopniu wpłynie na poprawę tej sytuacji. Potwierdzają to wyniki matury z 2009 i 2010 r. - informatyka i matematyka to były dwa przedmioty o najniższym odsetku zdających maturę na poziomie podstawowym (odpowiednio 78\% i 81/87\%, wg raportu CKE za 2009/2010 r.), a średni wynik matury z informatyki, zarówno na poziomie podstawowym, jak i rozszerzonym, był najniższy ze wszystkich przedmiotów (odpowiednio 40 i 35 p. w 2009 r., 47 i 38 p. w 2010 r., wg danych CKE). Badania OECD PISA 2009 wskazują, że na tle innych wysoko rozwiniętych krajów Europy, w tym najlepszej pod względem wyników z matematyki Finlandii, wypadamy stosunkowo słabo (choć należy zauważyć, iż Polska mieści się w grupie krajów o średnim wyniku).

Konieczne wydaje się więc podjęcie działań na rzecz rozwoju nie tylko przedsiębiorczości, ale także tych dwóch kompetencji kluczowych. Nie jest to łatwe, gdyż istnieje potrzeba przełamania strachu uczniów przed matematyką, która jawi się jako bardzo trudna dziedzina wiedzy. Choć uczniowie są bardzo chętni do zabawy z komputerem, nieco gorzej wygląda już sytuacja, kiedy trzeba opanować bardziej zaawansowane techniki komputerowe, szczególnie, jeśli wykorzystywane muszą być wiedza i umiejętności z zakresu matematyki. Nauczyciele stoją więc przed problemem, jak skutecznie kształtować postawy przedsiębiorcze uczniów w sytuacji, gdy przedmiot podstawy przedsiębiorczości nie ma dużej rangi w szkole (Kawecki 2005; Tracz, Rachwał 2007, 2008) i jak rozwijać kompetencje matematyczne i informatyczne w obliczu obaw uczniów przed trudnościami oraz często występującej niechęci do matematyki jako przedmiotu mało atrakcyjnego $\mathrm{i}$ - jak im się często wydaje - mocno teoretycznego, a przez to nieprzydatnego bezpośrednio w życiu.

Należy także zwrócić uwagę na niekorzystne tendencje związane z przemianami demograficznymi, tj. niżem dotykającym szkoły ponadgimnazjalne (głównie zawodowe), co stawia nauczycieli w niekorzystnej sytuacji zagrożenia utratą pracy w obliczu redukcji liczby klas i godzin. Umiejętność wykorzystania innowacyjnych strategii nauczania może dać im przewagę konkurencyjną na edukacyjnym rynku pracy.

Niezbędne wydaje się więc opracowanie nowej strategii edukacyjnej, ukierunkowanej na wzmocnienie kompetencji uczniów szkół ponadgimnazjalnych w zakresie kształtowania postaw przedsiębiorczych oraz rozwijania kompetencji matematycznych i posługiwania się technologiami informacyjnymi, którą mogliby wykorzystać w swojej pracy nauczyciele. Odpowiedzią na te potrzeby może stać się Projekt „Krok w przedsiębiorczość” (Innowacyjna strategia 2011). 


\section{Cele Projektu}

Głównym celem Projektu „Krok w przedsiębiorczość” jest opracowanie i pilotażowe wdrożenie (w woj. małopolskim i podkarpackim) innowacyjnego programu kształtowania postaw przedsiębiorczych, rozwijania kompetencji informatycznych i matematycznych w szkołach ponadgimnazjalnych. Przyjęty w jego ramach program kształcenia oparty jest na koncepcji tworzenia przez uczniów wirtualnej firmy (zlokalizowanej na Otwartej Platformie Edukacyjnej stworzonej na potrzeby Projektu) i konkurowania na wirtualnym rynku. Program ten może być wykorzystany powszechnie w szkołach ponadgimnazjalnych jako wiodąca metoda kształcenia w realizacji zajęć pozalekcyjnych lub w ramach przedmiotu podstawy przedsiębiorczości i nowego fakultatywnego przedmiotu ekonomia w praktyce, który zostanie wprowadzony zgodnie z harmonogramem reformy oświaty od roku szkolnego 2012/2013. W ramach Projektu przewiduje się również wypracowanie szeregu pomocniczych materiałów edukacyjnych dla nauczycieli (scenariusze zajęć, poradnik) oraz uczniów.

Ważniejsze cele szczegółowe Projektu „Krok w przedsiębiorczość” to:

- diagnozowanie i analizowanie stosowanych metod kształcenia oraz potrzeb środowiska szkolnego (głównie poprzez diagnostyczne warsztaty metodyczne i badania opinii nauczycieli), a także oczekiwań uczniów i pracodawców;

- przygotowanie innowacyjnego programu kształcenia opartego na koncepcji tworzenia przez uczniów wirtualnej firmy (zlokalizowanej na platformie internetowej) i konkurowania na wirtualnym rynku (przez okres jednego roku szkolnego); program jest oparty na nowej, holistycznej, interaktywnej metodzie kształcenia, bazującej na metodzie projektów z grupy metod aktywizujących;

- szczegółowe opracowanie, nazwanie, przetestowanie i rozpropagowanie nowej metody kształcenia w zakresie przedsiębiorczości, kompetencji matematycznych i informatycznych, którą można będzie wykorzystywać powszechnie w szkołach ponadgimnazjalnych;

- analizowanie podstawy programowej kształcenia ogólnego w IV etapie edukacyjnym pod kątem możliwości realizacji nowego innowacyjnego programu kształcenia oraz przedstawienie propozycji (jeśli okaże się to konieczne) modyfikacji podstawy programowej, głównie w zakresie podstaw przedsiębiorczości, matematyki, informatyki;

- przeszkolenie nauczycieli-opiekunów grup uczniowskich, reprezentujących szkoły zrekrutowane do uczestniczenia w fazie testowej Projektu, z zakresu jego realizacji (w tym prowadzenia zajęć przygotowawczych z uczniami);

- kształtowanie postaw przedsiębiorczości u uczniów poprzez przygotowanie biznesplanu, zakładanie i prowadzenie firmy w szkolnych zespołach, pod opieką nauczyciela;

- rozwijanie kompetencji informatycznych poprzez:

- przygotowanie planu działalności firmy w edytorze tekstu i zaprezentowanie go w programie do pokazów multimedialnych,

- wykorzystanie arkusza kalkulacyjnego do rozliczeń finansowych,

- zaprojektowanie stron WWW własnych firm i materiałów promocyjnych w programach graficznych,

- stałe wykorzystywanie Internetu i poczty elektronicznej w bieżącej działalności firmy, komunikacji z innymi członkami grupy i nauczycielem-opiekunem;

- praktyczne wykorzystanie wiedzy i umiejętności matematycznych w przygotowaniu planu finansowego działalności, prowadzeniu rozliczeń w trakcie działalności firmy, w tym przygotowywaniu cenników, ofert itp.;

- rozwijanie umiejętności radzenia sobie w sytuacjach niestandardowych poprzez funkcjonowanie na wirtualnym rynku, na którym będzie konieczność reakcji (odpowiedzi) na 
nietypowe zmiany sytuacji rynkowych (pojawienie się nowej oferty, zmiana sytuacji makroekonomicznej itp.);

- rozwijanie kreatywności uczniów poprzez przygotowanie przez nich nowatorskich pomysłów związanych z działalnością firmy (nazwa i logo przedsiębiorstwa, struktura organizacyjna, wygląd materiałów promocyjnych, kształt i zakres oferty);

- wypracowanie szeregu pomocniczych materiałów edukacyjnych w formie drukowanej i/lub elektronicznej dla nauczycieli (poradnik dotyczący wdrażania strategii kształcenia scenariusze zajęć) i uczniów.

Cele Projektu są zgodne z celem szczegółowym nr 3 określonym na poziomie Priorytetu III: Wysoka jakość systemu oświaty PO Kapitał ludzki, jako „Poprawa stopnia powiązania oferty w zakresie kształcenia i szkolenia z potrzebami rynku pracy przez liczbę opracowanych i upowszechnionych innowacyjnych programów nauczania w zakresie przedsiębiorczości”.

Główną ideą Projektu jest więc próba wykorzystania dużego zainteresowania uczniów przedsiębiorczością realizowaną nie w sposób encyklopedyczny, ale twórczy, w formie zespołowej pracy online nad planowaniem i prowadzeniem wspólnej działalności gospodarczej. W działaniach tych będzie konieczne praktyczne wykorzystanie umiejętności komputerowych (m.in. W zakresie posługiwania się edytorem tekstu, arkuszem kalkulacyjnym, programami graficznymi, technologiami komunikacyjnymi) oraz wybranych umiejętności matematycznych (w zakresie wykonywania obliczeń niezbędnych m.in. w planowaniu budżetu). Strategia zakłada wykorzystanie, jako podstawowego środka dydaktycznego, wirtualnego środowiska, jakim jest Otwarta Platforma Edukacyjna. Zaletą platformy jest jej z góry założone podobieństwo do programów do zarządzania projektami, z którymi uczniowie będą mogli się zetknąć w dorosłym życiu w każdej firmie. Ponadto, oprócz funkcji platformy edukacyjnej, jest ona środowiskiem pracy dydaktycznej, w którym uczeń może rozwiązywać różnego typu zadania (aktywności) podstawowe i dodatkowe (testy, quizy, krzyżówki), korzystać z bogatych zasobów materiałów edukacyjnych (w tym multimedialnych), komunikować się na forum i czacie z nauczycielem i innymi uczniami - członkami zespołu. Platforma jest też miejscem swoistej rozgrywki, gdyż zawiera elementy symulacji realnego życia gospodarczego dzięki możliwości przeprowadzania - w końcowym etapie realizacji zadań rzeczywistych, choć wirtualnie - transakcji gospodarczych.

Szczegółowa metodyka kształcenia w ramach wypracowanej Innowacyjnej strategii ksztatcenia została określona w załączonych do niej Kartach opisu Projektu jako składowych tej metodyki. Karty te przygotowano do każdego tematu realizowanego na zajęciach. Ponadto częściami składowymi przyjętej strategii kształcenia są scenariusze 50 zajęć szkolnych (z niezbędnymi załącznikami), poradnik dla nauczycieli oraz dodatkowe materiały edukacyjne dla uczniów w postaci przykładowego biznesplanu działalności firmy ze szczegółowymi wskazówkami jego wykonania.

Innowacyjność przygotowywanych w wyniku realizacji Projektu zmian w systemie kształtowania postaw przedsiębiorczych oraz kompetencji matematycznych i informatycznych polega więc, po pierwsze, na wykorzystaniu innowacyjnego środka dydaktycznego, którym jest wirtualna Otwarta Platforma Edukacyjna, a po drugie, na stworzeniu nowej metody zintegrowanego kształcenia wybranych kompetencji kluczowych, która może zostać wdrożona do edukacji jako rozwiązanie systemowe wraz z ewentualną propozycją modyfikacji zapisów obowiązującej podstawy programowej, które byłyby spójne z wykorzystaniem przygotowanej metody.

Podejście to, oparte na działaniach uczniów na wirtualnym rynku, symulującym realną rzeczywistość gospodarczą, jest rozwiązaniem zasadniczo różnym od dotychczasowego kształcenia $\mathrm{w}$ ramach podstaw przedsiębiorczości, opartego - jak wskazują badania - głównie na 
klasycznych metodach dydaktycznych. Mimo stosunkowo szerokiej oferty programów edukacyjnych i interaktywnych stron internetowych z zakresu przedsiębiorczości nie ma ogólnie dostępnej platformy, pozwalającej na tworzenie przez grupy uczniów firm funkcjonujących na wirtualnym rynku. Tego typu inicjatywy, choć pojawiały się w formie częściowej realizacji w ramach różnych projektów edukacyjnych, nie zostały wdrożone systemowo do edukacji.

Projekt „Krok w przedsiębiorczość” stwarza więc szansę na lepsze kształtowanie tych ważnych, z punktu widzenia funkcjonowania uczniów we współczesnym świecie i większego zainteresowania studiami na kierunkach ścisłych i technicznych, kompetencji kluczowych. Dzięki powiązaniu kształtowania postaw przedsiębiorczych z rozwojem kompetencji matematycznych i umiejętności komputerowych, może się on przyczynić do zwiększenia zainteresowania uczniów szkół ponadgimnazjalnych kontynuacją kształcenia na kierunkach o kluczowym znaczeniu dla gospodarki opartej na wiedzy.

\section{Grupy docelowe - odbiorcy Projektu}

Projekt kierowany jest przede wszystkim do nauczycieli przedsiębiorczości, a także osób uczących matematyki oraz informatyki w szkołach ponadgimnazjalnych. W fazie testowej Projektu przewidziano uczestnictwo nauczycieli i uczniów z 30 szkół w województwie małopolskim i podkarpackim, ale produkty wypracowane w ramach Projektu adresowane będą do nauczycieli wszystkich szkół w Polsce.

Grupy docelowe Projektu to:

1. na etapie testowania:

a) 30 nauczycieli szkół ponadgimnazjalnych w województwach małopolskim i podkarpackim,

b) 300 uczniów tych szkół ponadgimnazjalnych;

2. na etapie upowszechniania:

a) nauczyciele podstaw przedsiębiorczości i innych przedmiotów ekonomicznych oraz matematyki i informatyki z terenu całej Polski,

b) uczniowie szkół ponadgimnazjalnych z terenu całej Polski,

c) dyrektorzy szkół, przedstawiciele wojewódzkich kuratoriów oświaty, przedstawiciele jednostek samorządu terytorialnego (organów prowadzących), przedstawiciele ośrodków doradztwa metodycznego oraz ośrodków doskonalenia nauczycieli w Polsce.

Dodatkowo do grup odbiorców działań projektowych należy zaliczyć:

- uczestników konferencji organizowanych przez partnera Projektu (Uniwersytet Pedagogiczny w Krakowie) przy współpracy lidera Projektu (Nowa Era), tj. blisko 200 osób: nauczycieli uczących podstaw przedsiębiorczości i innych przedmiotów ekonomicznych, przedstawicieli ośrodków doradztwa metodycznego, pracowników szkół wyższych oraz dyrektorów szkół; na konferencjach prezentowane będą cele i założenia, przebieg oraz efekty realizacji fazy testowej Projektu;

- odbiorcy kolejnych tomów publikacji z niniejszej serii „Przedsiębiorczość - Edukacja”, wydawanej przez Zakład Przedsiębiorczości i Gospodarki Przestrzennej IG Uniwersytetu Pedagogicznego w Krakowie oraz wydawnictwo Nowa Era; w publikacjach opisane zostaną cele, założenia oraz efekty realizacji Projektu;

- młodzież w wieku 15-18 lat - odbiorcy kampanii społecznej mającej na celu uświadamianie istoty kształcenia kompetencji kluczowych, zwłaszcza przedsiębiorczości.

Realizacja Projektu powinna więc pomóc nauczycielom - w okresie reformy programowej kształcenia - dokonać takiej zmiany strategii nauczania przedsiębiorczości, aby uczniowie posiadali motywację do aktywnego udziału w kształceniu w tym zakresie oraz byli chętni do wyboru kierunków studiów inżynieryjno-technicznych o kluczowym znaczeniu dla gospodarki. 
Wypracowana strategia kształcenia może być włączona przez Ministerstwo Edukacji Narodowej w system edukacyjny i stanowić element polityki edukacyjnej w zakresie kształtowania tych ważnych, w warunkach rozwoju społeczeństwa informacyjnego, kompetencji kluczowych.

\section{Etapy realizacji Projektu}

Czas realizacji całego Projektu to sierpień 2010 - grudzień 2012. Zgodnie z założonym harmonogramem Projekt realizowany jest w trzech fazach.

Faza I - przygotowawcza: 01.08.2010-31.01.2011. Rozpoczęła się ona badaniem stopnia przygotowania uczniów szkół ponadgimnazjalnych z zakresu przedsiębiorczości, a także potrzeb i oczekiwań nauczycieli oraz przedsiębiorców w Polsce w zakresie edukacji ekonomicznej, umiejętności komputerowych i matematycznych związanych z prowadzeniem działalności gospodarczej. Zakończeniem stało się wypracowanie wstępnej wersji Innowacyjnej strategii kształcenia wraz ze szczegółową koncepcją funkcjonowania Otwartej Platformy Edukacyjnej;

Faza II - złożenia strategii do opinii Krajowej Sieci Tematycznej w obszarze „Edukacja i szkolnictwo wyższe" ${ }^{\text {"1 }}$ oraz akceptacji instytucji pośredniczącej (MEN) oraz zgłoszenia innowacji przez szkoły uczestniczące w Projekcie do kuratoriów oświaty: 01.02.2011-31.03.2011;

Faza III - wdrożeniowa (testowa): od 01.04.2011-31.11.2012. Została ona poprzedzona rekrutacją uczestników do Projektu; obejmuje następujące działania:

- praca na Otwartej Platformie Edukacyjnej (poprzedzona warsztatami szkoleniowymi dla użytkowników i przeprowadzeniem zajęć w szkole),

- przeprowadzenie konsultacji online przez nauczycieli i uczestnictwo w dyskusjach z uczniami poprzez narzędzia komunikacyjne platformy,

- przeprowadzenie analizy prac szkolnych zespołów projektowych,

- opracowanie raportu końcowego na temat funkcjonalności i efektów dydaktycznych uzyskanych w wyniku wykorzystania produktu finalnego,

- opracowanie końcowej wersji produktu finalnego oraz ostatecznych wersji materiałów edukacyjnych.

\section{Instytucje realizujące Projekt}

Projekt jest realizowany przez podmioty mające duże doświadczenie w zakresie opracowywania strategii edukacyjnych, kształcenia i doskonalenia nauczycieli oraz działalności publikacyjnej dla sektora oświatowego:

- wydawnictwo Nowa Era (lider Projektu) - wiodący wydawca podręczników szkolnych i innych publikacji edukacyjnych w Polsce, posiadający także duże doświadczenie w realizacji projektów edukacyjnych,

- Uniwersytet Pedagogiczny w Krakowie (partner) - najlepsza uczelnia pedagogiczna w Polsce (w świetle rankingu „Perspektyw” i „Rzeczpospolitej”) kształcąca nauczycieli od blisko 65 lat, specjalizująca się m.in. w badaniach naukowych z zakresu dydaktyk szczegółowych, w tym dydaktyki przedsiębiorczości (działalność ta jest skoncentrowana głównie w Zakładzie Przedsiębiorczości i Gospodarki Przestrzennej Instytutu Geografii, wydawcy serii „Przedsiębiorczość - Edukacja” oraz organizatora corocznych metodycznych konferencji naukowych poświęconych przedsiębiorczości i ogólnopolskich zjazdów nauczycieli tego przedmiotu),

\footnotetext{
${ }^{1}$ Na posiedzeniu KST w dnia 11 marca 2011 r. Projekt uzyskał jednoznaczną, bezwarunkową pozytywną opinię w sprawie realizacji fazy testowej.
} 
- Podkarpackie Centrum Edukacji Nauczycieli w Rzeszowie (partner) - wiodący ośrodek doskonalenia nauczycieli w Polsce (największy w województwie podkarpackim), posiadający duże doświadczenie w realizacji projektów edukacyjnych.

Ponadto w Projekt będą zaangażowani pracownicy innych instytucji naukowych i edukacyjnych w Polsce, w szczególności z uczelni ekonomicznych, pedagogicznych i ośrodków doskonalenia nauczycieli, doświadczeni nauczyciele oraz przedsiębiorcy - praktycy życia gospodarczego i trenerzy-psychologowie zarządzania.

\section{Oczekiwane efekty realizacji Projektu}

W wyniku opracowania Innowacyjnej strategii ksztatcenia w zakresie przedsiębiorczości oraz kształtowania kompetencji informatycznych i matematycznych z wykorzystaniem wirtualnej Otwartej Platformy Edukacyjnej oczekuje się następujących efektów:

- zwiększenie umiejętności poruszania się uczniów i uczennic w świecie biznesu i otwartego rynku pracy,

- zwiększenie wykorzystania elektronicznych narzędzi jako wsparcia edukacyjnego,

- uatrakcyjnienie prowadzonych w szkołach zajęć z podstaw przedsiębiorczości i możliwość zastosowania innowacji jako podstawowej, kompleksowej strategii kształcenia w ramach nowego przedmiotu ekonomia w praktyce (od 2012/2013),

- wsparcie nauczycieli w przekazywaniu trudnej wiedzy z zakresu przedsiębiorczości, powiązanej z wiedzą i umiejętnościami z zakresu matematyki i informatyki, w przystępny i ciekawy sposób,

- zwiększenie dostępu do wartościowych materiałów edukacyjnych zarówno w szkole, jak i w domu,

- zwiększenie zainteresowania studiami o kluczowym znaczeniu dla gospodarki, w tym studiami na kierunkach inżynierskich i matematyczno-przyrodniczych.

Do realizacji strategii kształcenia w szkołach - po zakończeniu Projektu - potrzebne są niewielkie nakłady finansowe i zmiany organizacyjne. Wystarczy tylko zdecydować się na jeden z zaproponowanych wariantów organizacyjnych, zainstalować darmowe oprogramowanie platformy z wszystkimi materiałami dodatkowymi (co ze względu na przyjęte rozwiązania techniczne nie będzie zadaniem trudnym), ustawić parametry gry i rozpocząć pracę. Oczywiście potrzebni są chętni uczniowie i nauczyciele, ale z tym nie powinno być problemu ze względu na atrakcyjność proponowanej strategii w stosunku do tradycyjnych metod kształcenia. Realizacja strategii wymaga zaangażowania nauczyciela w dyskusje z uczniami oraz ocenianie ich prac. Nagrodą powinno być jednak duże zaangażowanie uczniów i satysfakcja z osiąganych efektów kształcenia, a także świadomość uczestnictwa w procesie podnoszenia jakości pracy polskiej szkoły, szczególnie w kontekście wyzwań, które stawia wchodzenie w informacyjną fazę rozwoju cywilizacyjnego i budowa gospodarki opartej na wiedzy. 


\section{Literatura}

1. Borowiec M., Dorocki S., Jenner B., 2009, Wpływ zasobów kapitału ludzkiego na kształtowanie społeczeństwa informacyjnego i innowacyjności struktur przemysłowych [w:] Funkcje przemystu w kształtowaniu społeczeństwa informacyjnego, Z. Zioło, T. Rachwał (red.), „Prace Komisji Geografii Przemysłu PTG”, nr 13, Wydawnictwo Naukowe UP, Warszawa-Kraków, s. 95-109.

2. Commission Communication „Fostering entrepreneurial mindsets through education and learning”, COM (2006), 33 final.

3. Gierańczyk W., 2009, Rozwój społeczeństwa informacyjnego a przedsiębiorczość w krajach transformujących się [w:] Rola przedsiębiorczości w kształtowaniu społeczeństwa informacyjnego, Z. Zioło, T. Rachwał (red.), „Przedsiębiorczość - Edukacja”, nr 5, Nowa Era, Zakład Przedsiębiorczości i Gospodarki Przestrzennej Instytutu Geografii Uniwersytetu Pedagogicznego w Krakowie, Warszawa-Kraków, s. 19-36.

4. Innowacyjna strategia kształcenia w zakresie przedsiębiorczości oraz kształtowania kompetencji informatycznych i matematycznych z wykorzystaniem wirtualnej Otwartej Platformy Edukacyjnej opracowana w ramach Projektu ,Krok w przedsiębiorczość” (wstępna wersja), 2011, Nowa Era, Warszawa.

5. Kawecki Z., 2005, Ranga przedmiotu podstawy przedsiębiorczości w edukacji szkolnej [w:] Przedsiębiorczość a wspótczesne wyzwania edukacyjne, Z. Zioło, T. Rachwał (red.), „Przedsiębiorczość Edukacja”, nr 1, Wydawnictwo MiWa, Zakład Przedsiębiorczości i Gospodarki Przestrzennej Instytutu Geografii Akademii Pedagogicznej w Krakowie, Kraków, s. 203-206.

6. Kompetencje kluczowe w uczeniu się przez całe życie. Europejskie Ramy Odniesienia, 2007, Urząd Oficjalnych Publikacji Wspólnot Europejskich, Luxembourg.

7. Kompetencje kluczowe. Realizacja koncepcji na poziomie szkolnictwa obowiązowego, 2005, Eurydice, Fundacja Rozwoju Systemu Edukacji, Warszawa.

8. Kurek S., Rachwał T., 2010a, Założenia i wstepne wyniki europejskiego projektu badawczego FIFOBI w zakresie ksztattowania kompetencji uczniów gimnazjum do prowadzenia działalności gospodarczej [w:] Rola przedsiębiorczości w warunkach integracji europejskiej, Z. Zioło, T. Rachwał (red.), „Przedsiębiorczość - Edukacja”, nr 6, Nowa Era, Zakład Przedsiębiorczości i Gospodarki Przestrzennej Instytutu Geografii Uniwersytetu Pedagogicznego w Krakowie, Warszawa-Kraków, s. 472-485.

9. Kurek S., Rachwał T., 2010b, The Role of Business Education in the Development of Entrepreneurship in the Member States of the European Union, Europa XXI, Warszawa, s. 127-142.

10. Naudé W., 2008, Entrepreneurship in Economic Development. Research Paper No. 2008/20, World Institute for Development Economics Research, s. 1-47.

11. Rachwał T., 2004, Cele i treści kształcenia przedsiębiorczości w szkołach ponadgimnazjalnych [w:] Przedsiębiorczość stymulatorem rozwoju gospodarczego, J. Brdulak, M. Kulikowski (red.), Instytut Wiedzy SGH, Warszawa, s. 263-270.

12. Rachwał T., 2005a, Kształtowanie postaw uczniów na lekcjach przedsiębiorczości [w:] Przedsiębiorczość a współczesne wyzwania cywilizacyjne, Z. Zioło, T. Rachwał (red.), „Przedsiębiorczość - Edukacja”, nr 1, Wydawnictwo MiWa, Zakład Przedsiębiorczości i Gospodarki Przestrzennej Instytutu Geografii Akademii Pedagogicznej w Krakowie, Kraków, s. 137-144.

13. Rachwał T., 2005b, Podstawy przedsiębiorczości. Stownik, wyd. 2, Nowa Era, Warszawa.

14. Rachwał T., 2006, Ksztaltowanie postaw przedsiębiorczych w edukacji szkolnej [w:] Szkoła w nauce i praktyce edukacyjnej, B. Suchacka (red.), t. II, Oficyna Wydawnicza „Impuls”, Akademii Pedagogiczna w Krakowie, Kraków, s. 427-434.

15. Rachwał T., 2009, Ocena projektu zmian podstawy proramowej podstaw przedsiębiorczości [w:] Rola przedsiębiorczości w ksztaltowaniu społeczeństwa informacyjnego, Z. Zioło, T. Rachwał (red.), „Przedsiębiorczość - Edukacja”, nr 5, Nowa Era, Zakład Przedsiębiorczości i Gospodarki Przestrzennej Instytutu Geografii Uniwersytetu Pedagogicznego w Krakowie, Warszawa-Kraków, s. 349-372.

16. Rachwał T., 2010, Chapter 9. Entrepreneurship Education as a Growth Stimulus for Family Firms [w:] Exploring the Dynamics of Entrepreneurship, A. Surdej, K. Wach (ed.), A. Marszałek Publishing House, Toruń, s. 139-156. 
17. Recommendation of the European Parliament and of the Council of 18 December 2006 on key competences for lifelong learning (2006/962/EC). Official Journal of the European Union, L 394, 30.12.2006.

18. Szabó A., 2008. Education for entrepreneurship from kindergarden to adult learning. Prepared for the International Conference On Law, Economics And Management ICELM3, 4-7 June 2008 Targu-Muresh - Romania.

19. Szeliga P., 2007, Chwasty na polu przedsiębiorczości, czyli czego w szkole nie uprawiać [w:] Ksztattowanie postaw przedsiębiorczych a edukacja ekonomiczna, P. Wachowiak, M. Dąbrowski, B. Majewski (red.), Fundacja Promocji i Akredytacji Kierunków Ekonomicznych, Warszawa, s. 140-145.

20. Tracz M., Rachwał T., 2007, Przedmiot podstawy przedsiębiorczości - założenia realizacji a przygotowanie nauczycieli [w:] Rola przedsiębiorczości w aktywizacji gospodarczej, Z. Zioło, T. Rachwał (red.), „Przedsiębiorczość - Edukacja”, nr 3, Nowa Era, Zakład Przedsiębiorczości i Gospodarki Przestrzennej Instytutu Geografii Akademii Pedagogicznej w Krakowie, Warszawa-Kraków, s. 286-296.

21. Tracz M., Rachwał T., 2008, Metody i środki dydaktyczne stosowane przez nauczycieli podstaw przedsiębiorczości - wyniki badań [w:] Rola przedsiębiorczości w gospodarce opartej na wiedzy, Z. Zioło, T. Rachwał (red.), „Przedsiębiorczość - Edukacja”, nr 4, Nowa Era, Zakład Przedsiębiorczości i Gospodarki Przestrzennej Instytutu Geografii Uniwersytetu Pedagogicznego w Krakowie, WarszawaKraków, s. 325-330.

22. Wach K., 2007, Ksztaltowanie postaw przedsiębiorczych w programach nauczania. Stan obecny i proponowane kierunki zmian [w:] Ksztaltowanie postaw przedsiębiorczych a edukacja ekonomiczna, P. Wachowiak, M. Dąbrowski, B. Majewski (red.), Fundacja Promocji i Akredytacji Kierunków Ekonomicznych, Warszawa, s. 120-127.

23. Zioło Z., 2006, Rola przedsiębiorczości w podnoszeniu konkurencyjności społeczeństwa i gospodarki [w:] Rola przedsiębiorczości w podnoszeniu konkurencyjności społeczeństwa i gospodarki, Z. Zioło, T. Rachwał (red.), „Przedsiębiorczość - Edukacja”, nr 2, Nowa Era, Zakład Przedsiębiorczości i Gospodarki Przestrzennej Instytutu Geografii Akademii Pedagogicznej w Krakowie, Warszawa-Kraków, s. $10-17$.

24. Zioło Z., 2007, Rola przedsiębiorczości w aktywizacji gospodarczej-zarys modelu [w:] Rola przedsiębiorczości w aktywizacji gospodarczej, Z. Zioło, T. Rachwał (red.), „Przedsiębiorczość - Edukacja”, nr 3, Nowa Era, Zakład Przedsiębiorczości i Gospodarki Przestrzennej Instytutu Geografii Akademii Pedagogicznej w Krakowie, Warszawa-Kraków, s. 10-17.

25. Zioło Z., 2008, Ekonomiczne i społeczne uwarunkowania rozwoju gospodarki opartej na wiedzy [w:] Rola przedsiębiorczości w gospodarce opartej na wiedzy, Z. Zioło, T. Rachwał (red.), „Przedsiębiorczość - Edukacja”, nr 4, Nowa Era, Zakład Przedsiębiorczości i Gospodarki Przestrzennej Instytutu Geografii Uniwersytetu Pedagogicznego w Krakowie, Warszawa-Kraków, s. 12-23.

26. Zioło Z., 2009, Rola przedsiębiorczości w ksztaltowaniu społeczeństwa informacyjnego [w:] Rola przedsiębiorczości w kształtowaniu społeczeństwa informacyjnego, Z. Zioło, T. Rachwał (red.), „Przedsiębiorczość - Edukacja”, nr 5, Nowa Era, Zakład Przedsiębiorczości i Gospodarki Przestrzennej Instytutu Geografii Uniwersytetu Pedagogicznego w Krakowie, Warszawa-Kraków, s. 10-18.

27. Zioło Z., Rachwał T. (red.) 2005, Przedsiębiorczość a współczesne wyzwania cywilizacyjne, „Przedsiębiorczość - Edukacja”, nr 1, Wydawnictwo MiWa, Zakład Przedsiębiorczości i Gospodarki Przestrzennej Instytutu Geografii Akademii Pedagogicznej w Krakowie, Kraków.

28. Zioło Z., Rachwał T. (red.) 2006, Rola przedsiębiorczości w podnoszeniu konkurencyjności społeczeństwa i gospodarki, „Przedsiębiorczość - Edukacja”, nr 2, Nowa Era, Zakład Przedsiębiorczości i Gospodarki Przestrzennej Instytutu Geografii Akademii Pedagogicznej w Krakowie, Warszawa-Kraków.

29. Zioło Z., Rachwał T. (red.) 2007, Rola przedsiębiorczości w aktywizacji gospodarczej, „Przedsiębiorczość - Edukacja”, nr 3, Nowa Era, Zakład Przedsiębiorczości i Gospodarki Przestrzennej Instytutu Geografii Akademii Pedagogicznej w Krakowie, Warszawa-Kraków.

30. Zioło Z., Rachwał T. (red.), 2008, Rola przedsiębiorczości w gospodarce opartej na wiedzy, „Przedsiębiorczość - Edukacja”, nr 4, Nowa Era, Zakład Przedsiębiorczości i Gospodarki Przestrzennej Instytutu Geografii Uniwersytetu Pedagogicznego w Krakowie, Warszawa-Kraków. 
31. Zioło Z., Rachwał T. (red.) 2009, Rola przedsiębiorczości w kształtowaniu społeczeństwa informacyjnego, „Przedsiębiorczość - Edukacja”, nr 5, Nowa Era, Zakład Przedsiębiorczości i Gospodarki Przestrzennej Instytutu Geografii Uniwersytetu Pedagogicznego w Krakowie, Warszawa-Kraków.

32. Zioło Z., Rachwał T. (red.), 2010, Rola przedsiębiorczości w warunkach integracji europejskiej, „Przedsiębiorczość - Edukacja”, nr 6, Nowa Era, Zakład Przedsiębiorczości i Gospodarki Przestrzennej Instytutu Geografii Uniwersytetu Pedagogicznego w Krakowie, Warszawa-Kraków.

\section{The Aims and Objectives Of The Project "Step In Entrepreneurship" for Upper Secondary School Teachers}

This article presents the rationale and purpose of the Project "Step in entrepreneurship" to the secondary school teachers. The main objective of the project is to design and pilot testing of implementation (in Małopolska and Podkarpackie voivodeships) an innovative program of development of entrepreneurial attitudes, IT and mathematics competence in upper secondary schools. The developed training program is based on the concept of creating a virtual company by the students. It is located on the Open Educational Platform created specifically for the Project and the students compete on the virtual market. 